Trakya Eğitim Dergisi

Cilt 10, Sayı 3

Eylül 2020, 726-743

Geliș Tarihi: 21.08.2019

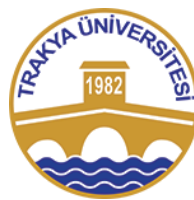

ISSN: $2630-6301$

Doi: $10.24315 /$ tred.608336

Araştırma Makalesi

Research Article
Trakya Journal of Education

Volume 10, Issue 3

September 2020, 726-743

Yayına Kabul Tarihi:31.08.2020

\title{
Öğretmenlik Alan Bilgisi Testlerindeki Organik Kimya Sorularının Yenilenmiş Bloom Taksonomisine Göre Analizi
}

\section{Analysis of Organic Chemistry Questions in Teaching Field Knowledge Tests According to the Revised Bloom Taxonomy}

\begin{abstract}
Hatice KARAER ${ }^{1}$
ÖZ: $\mathrm{Bu}$ araştırma, Öğretmenlik Alan Bilgisi Testlerindeki Organik Kimya sorularının Yenilenmiş Bloom Taksonomisine göre analiz etmek amacıyla yapılmıştır. $\mathrm{Bu}$ amaçla 20132019'daki Kimya ve Fen Bilimleri/Fen ve Teknoloji testlerdeki Organik Kimya ile ilgili 66 soru doküman inceleme tekniğiyle analiz edilmiştir. Elde edilen bulgulara göre soruların bilişsel süreç düzeyleri azdan çoğa doğru sıralandığında, "Uygulama" (\% 4,5), "Değerlendirme" $(\% 7,6)$, "Yaratma" $(\% 13,6)$, "Hatırlama" $(\% 19,7)$ ve "Anlama" $(\% 54,6)$ düzeylerinde soru bulunurken "Çözümleme" düzeyinde soru bulunmamaktadır. Soruların bilgi düzeyleri sırasıyla "Üstbilişsel”, (\%19,7), "Olgusal" (\%34,8), "Kavramsal" (\%45,5), șeklinde değișirken "İșlemsel" bilgi düzeyinde soru bulunmamaktadır. Soruların yıllara göre dağılımı incelendiğinde alt bilişsel düzeyde \%80,3 olurken "Üstbilişsel" düzeyde \%19,7 dağıldığ söylenebilir. Öğretmenlik Alan Bilgisi Testlerinde adayların uzmanlıklarını ortaya çıkartacak şekilde soruların hazırlanması, hazırlanırken Yenilenmiş Bloom Taksonomisin dikkate alınması ve soruların bilişsel süreç ve bilgi düzeylerine homojen dağıtılması önerilmektedir.

Anahtar sözcükler: Öğretmenlik alan bilgi testi, organik kimya, yenilenmiş Bloom taksonomisi, soru analizi.

ABSTRACT: The aim of this research is to analyse the questions Organic Chemistry in the Teacher Field Knowledge Tests according to the revised Bloom Taxonomy. For this purpose, 66 questions related to organic chemistry in Chemistry and Science/Science and Technology Teacher Field Knowledge Tests in 2013-2019 were analysed by document analysis technique. According to the findings, the distribution of the cognitive process levels of the questions are ranked from the least to the most as "Application" (4.5\%), "Evaluation" (7,6\%), "Creation" (13.6\%), "Remembering" (19,7\%), and "Comprehension" $(54,6 \%)$, while there are no questions at the "Analysis" level. While the knowledge levels of the questions are arranged as "Metacognitive", (19.7\%), "Factual" (34.8\%), "Conceptual" (45.5\%), there is no "Operational" level of knowledge. When the distribution of the questions by years is analyzed, it can be said that it was $80.3 \%$ at the sub-cognitive level and $19.7 \%$ at the "metacognitive" level. In Technology Teacher Field Knowledge Test, it is recommended to prepare the questions to reveal the expertise of the candidates, to consider the Renewed Bloom Taxonomy and to distribute the questions homogeneously to the cognitive process and knowledge levels.

Keywords: Teacher field knowledge test, organic chemistry,
\end{abstract} renewed bloom taxonomy, question analysis

Bu makaleye atıf vermek için:

Karaer, H. (2020). Öğretmenlik alan bilgisi testlerindeki organik kimya sorularının yenilenmiş Bloom taksonomisine göre analizi. Trakya Eğitim Dergisi, 10(3), 726-743

Cite this article as:

Karaer, H. (2020). Analysis of organic chemistry questions in teaching field knowledge tests according to the revised bloom taxonomy. Trakya Journal of Education, 10(3), 726-743

\section{Introduction}

\section{EXTENDED ABSTRACT}

The teaching profession is a profession as respected as it is so important. With the advance of science and technology, the importance of the teaching profession has increased even more. The professional development of the teachers influences the academic achievement of the students. According to Sünbül (1996), the success of teachers affects the success of the student. For all these reasons, successful teacher candidates must be selected and appointed. In Turkey, candidates who preference the teaching profession complete their undergraduate education and then are entered to the Public Personnel Selection Examination (PPSE) for appointment to the profession. According to the scores, candidates could be a teacher in the state schools. In the process up to 2013, while the General Ability Test, General Culture Test and Educational Sciences Test for PPSE was carried out for teacher 
exams, the Teacher Field Knowledge Test (TFKT) has been added in addition to these tests since 2013. The main factor in adding this test is the Basic Law of National Education, which defines the teaching profession as a profession that requires specialization.

Before the measurement tools are prepared, the targets must be identified and the taxonomies must be set up in a gradual sequence. Taxonomy provides important information about the learners' capacities as well as revealing differences in learning as much as possible in cognitive, emotional and psychomotor areas. Commonly used taxonomies in the cognitive field are Original Bloom taxonomy (OBT) or renewed Bloom taxonomy (RBT). Since 1956, OBT has been insufficient to identify the goals in the teaching process and to develop metacognitive skills desired by student- centred education, which is the essence of the constructivist approach, although it is acknowledged in the its gradual sequence. In 2001, Anderson and Krathwohl converted from a one-dimensional classification table to a two-dimensional classification table. According to Bümen (2006), setting a target in the RBT chart is an analytical journey and determining the primary target is this journey.

For this, it is first determined that the target corresponds to the level of knowledge and cognitive process by moving from the name and verb part, and then placed in the two-dimensional taxonomy table that the two levels coincide. When the literature is examined, there are many studies on the OBT. There are also studies based on the RBT. However, no studies have been seen to analyse the questions related to Organic Chemistry from the PPSE/TFKT questions according to the RBT.

This research is aimed to analyse the questions related to Organic Chemistry from the PPSE/TFKT questions according to the RBT.

\section{Method}

Analyses were carried out using the document analysis method. Document analysis is an analysis of materials that contain relevant information on the subject of research; it may be written materials or may be film, video, or photographs related to the subject materials. The data were collected from dokuman osym.gov.tr web site and from PPSE/TFKT prepared for Chemistry and Science/ Science/ Science and Technology teacher candidates. For this, 66 questions related to Organic Chemistry were collected by selecting from 520 PPSE/TFKT questions. In the analysis of the questions, the template developed according to the Bloom taxonomy was used. In the template, the cognitive process level of the problem and then the level of knowledge was determined. The question was placed at the intersection of both levels in the RBT table. Where there is more than one cognitive process level, the highest level was considered. The question is evaluated in two parts as name and verb. The name part of the problem was analyzed to correspond to the level of knowledge and verb cognitive process. The analyzes were shown to the experts in this field and the necessary arrangements were made in line with the opinions and suggestions. The analysis results are presented in tables.

\section{Discussion and Conclusion}

According to the findings, the distribution of the cognitive process levels of the questions from the least to the most were "Application" (4.50\%), "Evaluation" (7,6\%), "Creation" (13.6\%), "Remembering" (19.7\%), and "Comprehension" (54.6\%), while there are no questions at the "Analysis" level. When the level of knowledge of the questions was sorted from least to most, it changed to "Metacognitive (19.7\%), "Factual" (34.8\%), "Conceptual" (45.5\%) while there no questions at the and "Operational knowledge" level. The distribution of the questions by years was $78.8 \%$ in sub cognitive process levels and 21.2\% in "Metacognitive" level.

It can be seen that the distribution of questions according to the sub-steps of cognitive process levels is concentrated in certain steps. Similarly, it can be said that the questions are concentrated in the sub-steps in the distribution of knowledge according to the sub-steps.

From the findings obtained, it can be seen that the general distribution of the questions according to the level of knowledge and cognitive process similar to the results of the studies from the Bloom taxonomy in the literature. Our results shown that the questions related to the Organic Chemistry in the TFKTs have a low power for distinguishing successful teacher candidates from other candidates. The 
distinction of questions in the measuring instruments to be used in the selection of the teacher candidates must be high.

To sum up, the questions in the TFKTs should be prepared from high discriminatory questions in order to reveal the expertise of the candidates and they should be distributed homogenously at the cognitive process and knowledge levels considering the RBT.

\section{GİRIŞ̧}

Öğretmenlik, mesleklerin içinde saygınlığı olan, kutsal sayılan, önemi bilim ve teknolojik gelişmelerle daha da artan bir meslektir. Doktor, mühendis, avukat, vb. pek çok meslekte görev yapan kişilerin bulundukları mevkie gelmelerinde öğretmenlerin emekleri ve çabaları büyüktür. Öğretmenler öğrencilerini ülke menfaatleri doğrultusunda yetiştirirken aynı zamanda toplumun aydınlatılması ve gelişmesinde önemli rol oynarlar (Çelikten, Şanal \& Yeni, 2005; Oktay, 1991; Yılmaz, 2016). Öğretmenler öğrencilere rol model olacak kişilerin arasında olduğu için mesleki gelişimleri kendileri kadar öğrencileri içinde önemlidir. Guskey ve Sparks (1996), öğretmenlerin mesleki gelişimleriyle öğrencilerin akademik başarısı arasında anlamlı bir ilişki olduğunu ve öğretmenin başarısının öğrencinin başarısına yansıdığını belirtmiş̧lerdir (akt. Sünbül, 1996). Bu açıdan bakıldığında öğretmenlerin kariyerleri boyunca kendilerini çağın gereksinimlerini karşılayacak şekilde geliştirip yetiştirmeleri gerektiği kaçınılmaz bir gerçektir (Sabuncuoğlu, 2016). Bu gerçekten hareketle gelecekte başarılı öğretmenlerin olması için öncelikle nitelikli öğretmen adayların seçilmesi gerekir.

Türkiye'de öğretmenlik mesleğini tercih eden öğrenciler lisans eğitimlerini tamamladıktan sonra devlet okullarında öğretmen olarak atanmak için Kamu Personeli Seçme Sınavı (KPSS) ve mülakattan yeterli düzeyde puan almaları gerekir. Öğretmen adaylarının atanmalarında 2013 yılına kadar Genel Yetenek, Genel Kültür ve Eğitim Bilimleri Testlerindeki puanların oluşturduğu KPSS puanı yeterli olurken 2013 yılından günümüze kadar üç testin puanına ilave Öğretmenlik Alan Bilgisi Testi (ÖABT) puanı eklenmiştir. 2016'da bu dört testin puanının yanında mülakat getirilmiştir. Ayrıca 2013'den 2019'a kadar ÖABT soru sayıs1 50 olurken 2019'da 75'e yükseltilmiştir. KPSS puanına ÖABT eklenmesindeki gerekçeler arasında öğretmenlik uzmanlık gerektiren bir meslek olduğunu belirten Milli Eğitim Temel kanunu vardır (Oktay, 1991).

KPSS puanı kadar sınavda kullanılan ölçme araçlarının geçerlilik ve güvenilirliğinin yüksek olması, aynı zamanda başarılı öğretmen adaylarının diğer adaylardan ayırt edilmesinde oldukça önemlidir. Ölçme araçları, öğretmen adaylarının lisans eğitimlerinde hedef davranışların kazandırılıp kazandırılmadığı, verilen lisans eğitiminin başarılı olup olmadığı, başarı düzeylerinde adayların cinsiyeti, mezun oldukları üniversite vb. değişkenlere göre nasıl değiştiği hakkında önemli geri bildirimler vermektedir. Bu nedenle ölçme araçları hazırlanmadan önce hedeflerin belirlenmesi, aşamalı olarak sıralanması ve taksonomilerin oluşturulması önemlidir.

Taksonomi bilişsel, duyuşsal ve psikomotor alanlardaki öğrenme farklılıklarını ortaya çıkardığı gibi öğrencilerin kapasitelerine göre neyi öğrendikleri hakkında da önemli bilgiler vermektedir. Bilişsel alan, bilginin kazanılması ve uygulanmasıyla ilgili olup öğrencinin okuduğunu anlaması, anladığını yorumlaması vb. zihinsel süreçteki özellikleri hakkında bilgiler içermektedir (Bümen, 2006; Tutkun \& Okay, 2011). Bilişsel alanla ilgili istendik davranışları kolaydan zora, basitten karmaşığa vb. birbirini takip edecek şekilde aşamalı olarak sıralama olană̆ sağlayan ve yaygın olarak kullanılan sınıflandırma 1956'da Bloom'un geliştirdiği orijinal taksonomisidir (OBT).

OBT, o günden bugüne kadar kabul görse de yapılandırmacı yaklaşımın özünü oluşturan öğrenci merkezli eğitimin arzu ettiği üstbilişsel becerileri ortaya çıkartmada bazı eksikliklerinin olduğu belirlenmiştir. Ayrıca programların yapılandırılmasına paralel olarak taksonomi çalışmalarının da yapılandırılması ve güncellenmesi gerektiğini düşünen Anderson \& Krathwohl (2001), OBT'de "biliş üstü bilgi" kavramını bilgi düzeyine ekleyerek tek boyutlu taksonomi tablosunu iki boyutlu Yenilenmiş Bloom Taksonomisine (YBT) dönüştürmüşlerdir (Tutkun \& Okay, 2011; Tutkun, Demirtaş, GürErdoğan \& Arslan, 2005).

OBT tablosunda sadece bilişsel süreç düzeyleri bulunurken YBT tablosunda bilişsel süreç ve bilgi düzeyleri bulunmaktadır. Her iki tabloda "Değerlendirme" ve "Uygulama" düzeylerinin adları 
değişmezken diğer düzeylerin adları değişmiştir. OBT'de "Sentez" düzeyi "Değerlendirme" düzeyinden önce gelirken, YBT'de "Yaratma" düzeyi "Değerlendirme" düzeyinden sonra gelmektedir. YBT tablosunda bilimsel okuryazarlığı ortaya çıkartacak üstbilişsel bilgi düzey bulunmaktadır. YBT bütün bu özelliklere bağlı olarak günümüzdeki yapılandırmacı yaklaşıma daha uygun, dünyada kullanılabilirliği daha yüksek, esnek olduğu kadar öğretim sürecine güncellik getirebilecek ve güncelliğini koruyabilecek özelliklere sahiptir (Beyrekli \& Sönmez, 2017; Tutkun, Demirtaş \& GürErdoğan, 2015; Yurdabakan, 2012). YBT tablosunda bir hedefi yerleştirmek analitik bir yolculuktur ve bu yolculukta öncelik hedefi belirlenmekten geçmektedir.

Bir hedefin isim ve fiil kısmından hareketle bilgi ve bilişsel süreç düzeylerinin hangilerine karş1lık geldiği belirlenir ve YBT tablosunda (Tablo 5) iki düzeyin çakıştığı yere yerleştirilir (Bümen, 2006). YBT'ye göre bilişsel süreç düzeyleri ve alt basamakları Tablo 1'de bilgi düzeyleri ve alt basamakları Tablo 2'de verilmiştir.

Tablo 1.

YBT'ye göre bilişsel süreç düzeyleri ve alt basamakları

\begin{tabular}{llll}
\hline Bilişsel süreç düzeyleri & Alt basamakları & Bilişsel süreç düzeyleri & Alt basamakları \\
\hline 1. Hatırlama & 1. Tanıma & 4. Analiz Etme / Çözümleme & 1. Ayrıştırma \\
& 2. Anımsama & & 2. Örgütleme \\
2. Anlama & 3. Atıfta bulunma \\
& $\begin{array}{l}\text { 1. Yorumlama } \\
\text { 2. Örnekleme }\end{array}$ & 5. Değerlendirme & 1. Denetim yapma \\
& 3. Sinıflama & & 2. Eleştirme \\
& 4. Özetleme & & \\
& 5. Çıarım Yapma & 6. Yaratma & 1. Oluşturma \\
& 6. Karşılaştırma & & 2. Planlama \\
& 7. Açılama & & 3. Üretme \\
& 1.Yürütme & & \\
2. Kullanma & & \\
\hline
\end{tabular}

Tablo 1'de YBT'nin bilişsel süreç düzeyleri altı düzey ve on dokuz alt basamaktan oluşmaktadır (Krathwohl, 2002).

Tablo 2.

YBT’ye göre bilgi düzeyleri ve alt basamaklart

\begin{tabular}{ll}
\hline Bilgi Düzeyi & Alt Basamağı \\
\hline A. Olgusal Bilgi & A. Terimler bilgisi \\
& B. Özel detay ve öğeler bilgisi \\
B. Kavramsal Bilgi & A. Sinıflama ve kategori bilgisi \\
& B. İlke ve genellemeler bilgisi \\
& C. Teoriler, modeller ve yapılar bilgisi \\
C. İşlemsel Bilgi & A. Konuyla ilgili beceri ve işlem aşamaları bilgisi \\
& B. Konuyla ilgili yöntem ve teknik bilgisi \\
& C. Uygun duruma göre yöntemin nasıl kullanılacağı ile ilgili ölçüt bilgisi \\
D. Üstbilişsel Bilgi & A. Stratejik bilgi \\
& B. Bilişsel görevlerle ilgili bilgi \\
& C. Bireyin kendine dönük biliş ve öğrenmeyle ilgili bilgisi \\
\hline
\end{tabular}

Tablo 2'de YBT'nin bilgi düzeyinde dört düzey ve on bir alt basamak bulunmaktadır (Krathwohl, 2002).

YBT ile ilgili yapılmış çalışmaların çoğunluğu ölçme değerlendirme süreçleri üzerinde yoğunlaşmış olmakla birlikte (Beyrekli \& Sönmez, 2017) literatürde OBT ve YBT ile ilgili yapılmış çok sayıda çalışma bulunmaktadır (Akanngbe \& Enero, 2015; Anderson. \& Krathwohl, 2001; Amer, 2006; Arseven, Şimşek \& Güden, 2016; Ayvacı \& Türkdoğan, 2010; Ayvacı \& Şahin, 2009; Azar, 2005; Darwazeh \& Branch, 2015; Dindar \& Demir, 2006; Durukan \& Demir, 2017; Edwards, 2010; Eke, 2015; Ermurat, Gümüş, Kurt \& Feyatörbay, 2011; Eroğlu \& Sarar-Kuzu, 2014; Geçit \& Yarar, 2010; Gezer, Şahin, Öner-Sünkür \& Meral, 2014; Gökler, Aypay \& Ar1, 2012; Gökulu, 2015; Güler, Özdemir \& Dikici, 2012; Gündüz, 2009; Karaman, 2005; Korkmaz \& Ünsal, 2015; Köğce \& Baki, 2009; Krathwohl, 2002; Mohammadi, Kiany, Ghafar, Samar \& Akbari, 2015; Omara, Harisa, Hassana, 
Arshada, Rahmata, Zainala \& Zulkifli, 2012; Özdemir, Altık \& Baki, 2015; Özer-Keskin \& Aydın, 2011; Seo, Kim \& Chae, 2010; Şanlı \& Pınar, 2017; Tanık \& Saraçoğlu, 2011; Taşan \& Bektaş, 2016; Tikkanen \& Aksela, 2012; Topçu, 2017; Tsaparlis \& Zoller, 2003; Tutkun, Demirtaş \& Gür-Erdoğan, 2015; Tutkun, Demirtaş, Gür-Erdoğan \& Arslan, 2005; Upahi, Issa \& Oyelekan, 2015; Üner, Akkuş \& Kormal1, 2014; Yurdabakan, 2012). Literatürde KPSS/ÖABT'lerindeki Analitik Kimya ile ilişkili soruların YBT göre analizini içeren çalışma (Karaer, 2019) bulunurken Organik Kimya sorularının YBT'ye göre analizini içeren herhangi bir çalışmaya rastlanmamıştır.

Bu araştırma, 2013-2019 KPSS-ÖABT sorularından Organik Kimya sorularının YBT’ye göre analiz etmek amacıyla yapılmıştır. Araştırmada ÖABT'lerdeki Organik Kimya sorularının YBT'ye göre analizlerini gösteren örneklerin olması, örneklerde ayrıntılı şekilde analizlerin nasıl yapıldığının açıklanması ve bu alanda araştırmacılara yol gösterici olacağının düşünülmesi nedeniyle alana katkı sağlayacağı söylenebilir. Ayrıca bugüne kadar ÖABT’lerdeki Organik Kimya sorularının, hangi bilişsel süreç ve bilgi düzeylerinde yoğunlaştığını gösterdiği için KPSS-ÖABT sorularnı hazırlayan ekibe, öğretim elemanlarına ve öğretmen adaylarına Organik Kimya sorularıyla ilgili önemli bilgiler vereceği düşünülmektedir.

ÖABT'lerdeki Organik Kimya sorularının YBT'ye göre analiz edildiğinde soruların bilişsel süreç ve bilgi düzeylerinin dağılımı nasıldır? Sorusu araştırmanın ana problemi olarak belirlenmiş ve aşağıdaki alt problemlerin yanıtı aranmıştır.

1. ÖABT'lerdeki Organik Kimya sorularının bilgi ve bilişsel süreç düzeylerinin dağılımı nasıldır?

2. ÖABT'lerdeki Organik Kimya sorularının bilişsel süreç düzeylerinin yıllara göre dağılımı nasıldır?

3. ÖABT'lerdeki Organik Kimya sorularının bilgi düzeylerinin yıllara göre dağglımı nasıldır?

4. ÖABT'lerdeki Organik Kimya sorularının bilişsel süreç düzeylerinin alt basamaklarının yıllara göre dağılımı nasıldır?

5. ÖABT'lerdeki Organik Kimya sorularının bilgi düzeylerinin alt basamaklarının yıllara göre dağ 11 ımı nasıldır?

\section{YÖNTEM}

Araştırmada doküman analizi tekniği kullanılmıştır. Doküman analizi, araştırma konusuyla ilgili bilgileri içeren materyallerin (kitap, dergi vb. yazılı materyaller ile film, video veya fotoğraflar görsel materyal) analizi olup hangi dokümanların analiz edileceğini araştırmanın problemine göre karar verilir. Doküman analizi veri toplama aracı olarak kullanılabileceği gibi görüşme ve gözlemler sonucu elde edilen verileri ilişkilendirmek içinde kullanılabilmektedir (Cansız Aktaş, 2014). Bu araştırmada veri toplama aracı olarak kullanılmıştır.

\section{Araştırmanın Örneklemi}

Araştırmanın örneklemini, dokuman.osym.gov.tr internet adresinde yayınlanmış ve KPSS'de Kimya ve Fen Bilimleri/Fen ve Teknoloji ÖABT'lerdeki 520 sorudan Organik Kimya ile ilgili 66 soru oluşturmaktadır. Araştırmada örnekleme çeşitlerinden amaçlı örnekleme tercih edilmiştir. Amaçlı örnekleme uzun zamana yayılan, derinlemesine analiz etme olanağı sağlayan ve zengin bilgi içerdiği düşünülen durumların derinlemesine incelenmesine firsat vermektedir. Soruların yıllara göre dağılımının frekans ve yüzdeleri Tablo 3'de verilmiştir.

Tablo 3.

KPSS-ÖABT sorularından organik kimya il ilgili soruların yıllara göre dă̆ılımı

\begin{tabular}{lcccccccccccccc}
\hline & 2013 & 2014 & \multicolumn{2}{c}{2015} & \multicolumn{2}{c}{2016} & 2017 & \multicolumn{3}{c}{$2018-2019$} & \multicolumn{2}{c}{ Toplam } \\
& $\mathrm{f}$ & $\%$ & $\mathrm{f}$ & $\%$ & $\mathrm{f}$ & $\%$ & $\mathrm{f}$ & $\%$ & $\mathrm{f}$ & $\%$ & $\mathrm{f}$ & $\%$ & $\mathrm{f}$ & $\%$ \\
\hline Kimya & 10 & 76,9 & 10 & 83,3 & 11 & 84,6 & 11 & 84,6 & 10 & 83,3 & 2 & $?$ & 54 & 81,8 \\
Fen Bil./Fen ve Tek. & 3 & 23,1 & 2 & 16,7 & 2 & 15,4 & 2 & 15,4 & 2 & 16,7 & 1 & $?$ & 12 & 18,2 \\
Toplam & 13 & 100 & 12 & 100 & 13 & 100 & 13 & 100 & 12 & 100 & 3 & $?$ & 66 & 100 \\
\hline
\end{tabular}

Tablo 3'e göre soruların \%81,8'i Kimya; \%18,2'si Fen Bilimleri/Fen ve Teknoloji ÖABT'den alınmıştır. 2018 ve 2019'a ait Organik Kimya sorularının frekansı verilmiş ancak soruların \%10’u yayınlandığı için yüzdeleri verilmemiştir.

Verilerin Toplanması ve Analizi 
Araştırmanın verileri, dokuman inceleme tekniğiyle 2013-2019 KPSS-ÖABT’lerdeki sorulardan Organik Kimya ile ilgili 66 sorunun içerik analizinden toplanmıştır. Soruların içerik analizinde bilişsel süreç ve bilgi düzeyleri belirlenirken araştırmacının geliştirdiği şablon (Ek 1) kullanılmıştır. Bunun için sorular "isim" ve "fiil" olarak iki kısma ayrılmış ve isim kısmı bilgi düzeyine "fiil”" kısmı bilişsel süreç düzeyine karşılık gelecek şekilde analizler yapılmıştır.

Soruların önce bilişsel süreç düzeyleri sonra bilgi düzeyleri belirlenmiş ve YBT tablosunda her iki düzeyin çakıştığı yere yerleştirilmiştir (Tablo 5). Yerleştirmede bilişsel süreç düzeyi birden fazla olduğu düşünülen sorularda diğer alt düzeyleride içeren en üst düzey alınmıştır. Örneğin, "Anlama" ve "Uygulama" düzeylerinin bir arada olduğu düşünülen bir sorunun bilişsel süreç düzeyi için "Hatırlama" ve "Anlama" düzeylerini de kapsayan "Uygulama" düzeyi alınmış ve yerleştirme ona göre yapılmıştır.

Tablo 4.

ÖABT sorulardan organik kimya ile ilgili soruların YBT bilişsel süreç ve bilgi düzeyleri

\begin{tabular}{lllllll} 
& 1. & 2. & 3. & 4. & 5. & 6. \\
& Hatırlama & Anlama & Uygulama & Çözümleme & Değerlendirme & Yaratma \\
\hline A. Olgusal & & & & & & \\
B. Kavramsal & & & & & & \\
C. İşlemsel & & & & K/24/DB/51 & \\
D. Üstbilişsel & & & & \\
\hline
\end{tabular}

Soruların Tablo 4'de gösterildiği şeklide YBT'ye yerleştirilmesi yapılmıştır. Örneğin Şekil 5'de gösterilen ve Örnek 4 olarak verilen 2017/ÖABT'deki 24'üncü sorunun bilişsel süreç ve bilgi düzeyleri YBT'de K/24/DB/51 şeklinde gösterilmiştir. Bu gösterimde K: Kimya testinden alındığını; 24: Testteki soru numarasını; D: Bilgi düzeyini; B: Bilgi düzeyinin alt basamağını, 5: Bilişsel süreç düzeyini ve 1: Bilişsel süreç düzeyinin alt basamağını ifade etmektedir.

Aşağıda soru analizlerinin nasıl yapıldığını gösteren altı örnek verilmiştir (Şekil 1-6). Örneklerin üçü Fen Bilimleri/Fen ve Teknoloji; üçü Kimya ÖABT’ den alınmıştır.

\begin{tabular}{|c|c|c|c|c|}
\hline \multicolumn{3}{|c|}{ Testin Adı: Fen Bil. /Fen ve Tek. } & Testin Yılı: 2013 & Testteki Soru No: 23 \\
\hline \multicolumn{3}{|c|}{ 23. :Ö $=\ddot{N}-C \equiv N$ : } & \multirow{9}{*}{\multicolumn{2}{|c|}{$\begin{array}{l}\text { İsim Kısmı: Molekülde I ve II ile gösterilen } \\
\text { azot atomlarının formal yükü doğru } \\
\text { Fiil Kısmı: Verilmiştir? } \\
\text { Bilisssel Süreç Boyutu: } 3 \\
\text { Alt Basamağı:2 } \\
\text { Bilgi Boyutu: B } \\
\text { Alt Basamağı: B } \\
\text { YBT Tablosunda Yeri: B3 } \\
\text { YBT Tablosunda Gösterimi: F/23/BB/32 }\end{array}$}} \\
\hline & & & & \\
\hline \multicolumn{3}{|c|}{$\begin{array}{l}\text { molekülünde I ve II ile gösterilen azot atomlarının } \\
\text { formal yükü, aşağıdakilerin hangisinde doğru } \\
\text { olarak verilmiştir? }\end{array}$} & & \\
\hline & $\mathbf{I}$ & 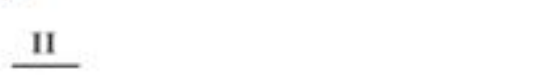 & & \\
\hline A) & o & 1 & & \\
\hline & 1 & & & \\
\hline$)$ & 0 & 0 & & \\
\hline D) & -1 & 1 & & \\
\hline E) & 1 & -1 & & \\
\hline \multicolumn{5}{|c|}{ 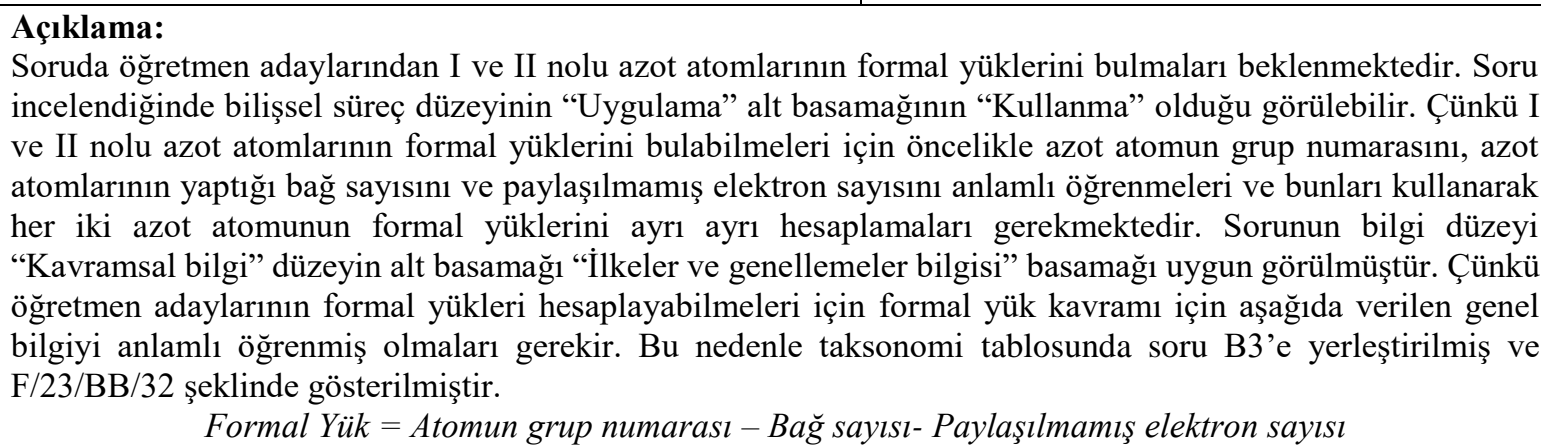 } \\
\hline
\end{tabular}

Sekil 1. 2013 Fen bilimleri/fen ve teknoloji ÖABT'deki 23. Sorunun YBT'ye göre analizi 
ÖRNEK 2.

\begin{tabular}{|c|c|}
\hline Testin Adı: Fen Bil. /Fen ve Tek. & Testin Yılı: 2014 \\
\hline $\begin{array}{l}\text { 24. } \mathrm{H}_{3} \mathrm{C}-\mathrm{CH}=\mathrm{CH}-\mathrm{CH}_{2}-\mathrm{CH}-\mathrm{CH}_{3} \\
\text { bilesiginin IupAC sistemine göre } \\
\text { adi asağldakilerden hangisidir? } \\
\text { A) 5-etil-2-heksen } \\
\text { B) 2-etil-4-heksen } \\
\text { C) 5-metil-2-hepten } \\
\text { D) 3-metil-5-hepten } \\
\text { E) 5-metil heptan }\end{array}$ & $\begin{array}{l}\text { İsim Kısmı: Bileşiğin IUPAC sistemine göre adı } \\
\text { Fiil Kısmı: Hangisidir? } \\
\text { Bilişsel Süreç Boyutu: } 2 \\
\text { Alt Basamağı: } 2 \\
\text { Bilgi Boyutu: A } \\
\text { Alt Basamağı: B } \\
\text { YBT Tablosunda Yeri: A2 } \\
\text { YBT Tablosunda Gösterimi: F/24/AB/22 }\end{array}$ \\
\hline \multicolumn{2}{|c|}{$\begin{array}{l}\text { Açıklama: } \\
\text { Soruda öğretmen adaylarının IUPAC sistemine göre alkenlerin adlandırılmasıyla ilgili bilgileri } \\
\text { sorgulanmaktadır. Adayların verilen bileşiği adlandırabilmeleri için IUPAC sistemine göre adlandırmanın nasıl } \\
\text { yapıldığı hakkında yeterli bilgiye sahip olmaları gerekir. Bu nedenle sorunun bilişsel süreç düzeyi "Anlama", } \\
\text { alt basamağı "Örnekleme" olduğu söylenebilir. Sorunun bilgi düzeyi "Olgusal bilgi"; alt basamağ "Özel detay } \\
\text { ve öğeler bilgisi” olarak uygun görülmüştür. Çünkü IUPAC sistemine göre adlandırma dünyanın her yerinde } \\
\text { aynı olduğu ve alkenlerin adlandırması konusunu içerdiği için taksonomi tablosunda A2'ye yerleştirilmiş ve } \\
\text { F/24/AB/22 şeklinde gösterilmiştir. }\end{array}$} \\
\hline
\end{tabular}

Şekil 2. 2014 Fen bilimleri/fen ve teknoloji ÖABT'deki 24. Sorunun YBT’ye göre analizi

\section{ÖRNEK 3.}

\begin{tabular}{|c|c|}
\hline Testin Adr: Fen Bil. /Fen ve Tek. & Testteki Soru No: 25 \\
\hline 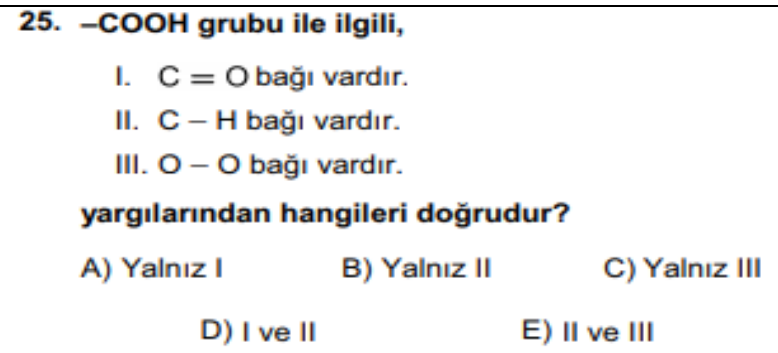 & $\begin{array}{l}\text { İsim Kısmı: -COOH grubu ile ilgili yargılardan } \\
\text { Fiil Kısmı: Hangileri doğrudur? } \\
\text { Bilişsel Süreç Boyutu: } 1 \\
\text { Alt Basamağı: } 1 \\
\text { Bilgi Boyutu: A } \\
\text { Alt Basamağı: A } \\
\text { YBT Tablosunda Yeri: A1 } \\
\text { YBT Tablosunda Gösterimi: F/25/AA/11 }\end{array}$ \\
\hline $\begin{array}{l}\text { Soruda öğretmen adaylarının fonksiyonel gruplardan } \\
\text { Adaylardan herhangi bir yorum yapmadan verilen ö } \\
\text { için bilişsel süreç düzeyi "Hatırlama" alt basamăg } \\
\text { Sorunun bilgi düzeyi için "Olgusal bilgi", düzeyin a } \\
\text { öncüllerde verilen bazı bilgiler karboksil grubuna y } \\
\text { düzeyin çakıștı̆̆ı A1'e yerleştirilmiș ve F/25/AA/11 }\end{array}$ & $\begin{array}{l}n \text { hareketle doğru seçeneği bulmaları beklendiği } \\
\text { a/Fark etme" basamağı olduğu düşünülmüš̈tür. } \\
\text { ğg "Terimler bilgisi" uygun görülmüştür. Çünkü } \\
\text { gilerdir. O yüzden taksonomi tablosunda her iki } \\
\text { gösterilmiştir. }\end{array}$ \\
\hline
\end{tabular}

Şekil 3. 2016 Fen bilimleri/fen ve teknoloji ÖABT'deki 25. sorunun YBT'ye göre analizi

ÖRNEK 4.

\begin{tabular}{|l|l|l|}
\hline Testin Adı: Kimya ÖABT & Testin Yılı: 2013 & Testteki Soru No: 25 \\
\hline
\end{tabular}




\begin{tabular}{|c|c|}
\hline $\begin{array}{l}\mathrm{CH}_{3} \\
\text { lo soodyum otoksit ile olan } \\
\text { olusmass beklenen alken } \\
\text { lgisidir? }\end{array}$ & $\begin{array}{l}\text { İsim Kısmı: Bileşiğin etanol içinde sodyum } \\
\text { etoksit ile olan ayrılma tepkimesi sonucu } \\
\text { oluşması beklenen alken yapısı } \\
\text { Fiil Kısmı: Hangisidir? } \\
\text { Bilişsel Süreç Boyutu: } 6 \\
\text { Alt Basamağı: 1 } \\
\text { Bilgi Boyutu: D } \\
\text { Alt Basamağı: B } \\
\text { YBT Tablosunda Yeri: D6 } \\
\text { YBT Tablosunda Gösterimi: K/25/DB/61 }\end{array}$ \\
\hline $\begin{array}{l}\text { Açıklama: } \\
\text { Öğretmen adaylarının organik tepkime mekanizmalar } \\
\text { tepkimelerinden } \beta \text {-eliminasyonu tepkime mekanizmasır } \\
\text { sorgulanmaktadır. Soruda verilen maddeden ürüni } \\
\text { seçeneklerden hangi maddenin olabileceğini tahmin et } \\
\text { verilen bileşikteki halojenüre (bromüre) komşu } \beta \text {-karbo } \\
\text { vermeleri ve sentez sonucunda oluşacak ana ürünü seç } \\
\text { "Yaratma", düzeyin alt basamağı "Oluşturma" olarak d } \\
\text { düzeyin alt basamağı "Bilişsel görevlerle ilgili bilgi" b } \\
\text { verilen bileşikten oluşacak ana ürünü belirleyebilmele } \\
\text { karar verecekleri için taksonomi tablosunda D6'ya yerl }\end{array}$ & $\begin{array}{l}\text { an Ayrılma (Eliminasyon) tepkimelerini, ayrılma } \\
\text { e mekanizmaya göre ürün oluşumuyla ilgili bilgileri } \\
\text { entezlenip sentezlenemeyeceğini ve ana ürünü } \\
\text { leri beklenmektedir. Bunun için öğretmen adayları } \\
\text { andaki hidrojenlerden hangisinin ayrılacağına karar } \\
\text { klerde bulmaları gerektiği için bilisssel süreç düzeyi } \\
\text { nülmüşș̈ür. Sorunun bilgi düzeyi "Üstbilişsel bilgi”, } \\
\text { mağı uygun görülmüştür. Çünkü öğretmen adayları } \\
\text { çin bilişsel görevlerle ilgili bilgilerinden hareketle } \\
\text { rilmiş ve K/25/DB/61 şeklinde gösterilmiştir. }\end{array}$ \\
\hline
\end{tabular}

Şekil 4. 2013 Kimya ÖABT'deki 25. sorunun YBT'ye göre analizi

ÖRNEK 5.

\begin{tabular}{|c|c|}
\hline Testin Adı: Kimya ÖABT & Testteki Soru No: 24 \\
\hline 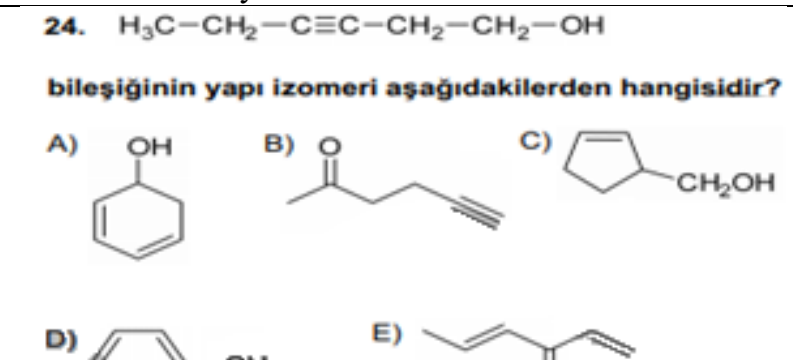 & $\begin{array}{l}\text { İsim Kısmı: Bileşiğin yapı izomeri } \\
\text { Fiil Kısmı: Hangisidir? } \\
\text { Bilişsel Süreç Boyutu: } 2 \\
\text { Alt Basamağı: } 2 \\
\text { Bilgi Boyutu: B } \\
\text { Alt Basamağı: C } \\
\text { YBT Tablosunda Yeri: B2 } \\
\text { YBT Tablosunda Gösterimi: K-24/BC/22 }\end{array}$ \\
\hline $\begin{array}{l}\text { Açıklama: } \\
\text { Soruda öğretmen adaylarının yapı izomeri kavramı ile ilg } \\
\text { anlamlı ögrenen bir öğretmen adayı seçeneklerdeki bil } \\
\text { olduğuna karar verebilir. Bu nedenle sorunun bilişs } \\
\text { "Örnekleme" olarak uygun görülmüştür. Soruda "Yapı } \\
\text { "Kavramsal bilgi", düzeyin alt basamağ "Teoriler, } \\
\text { taksonomi tablosunda B2"ye yerleştirilmiş ve K-24/BC/2 }\end{array}$ & $\begin{array}{l}\text { ilgileri sorgulanmaktadır. Yapı izomeri kavramını } \\
\text { klerden hangisinin verilen bileşiğin yapı izomeri } \\
\text { süreç düzeyi "Anlama”, düzeyin alt basamağı } \\
\text { neri kavramı" bilgisi sorguladığı için bilgi düzeyi } \\
\text { eller ve yapılar bilgisi” basamağı düşünülerek } \\
\text { eklinde gösterilmiştir. }\end{array}$ \\
\hline
\end{tabular}

Şekil 5. 2014 Kimya ÖABT'deki 24. sorunun YBT'ye göre analizi 
ÖRNEK 6.

\begin{tabular}{|c|c|}
\hline Testin Adı: Kimya ÖABT & Testteki Soru No: 25 \\
\hline 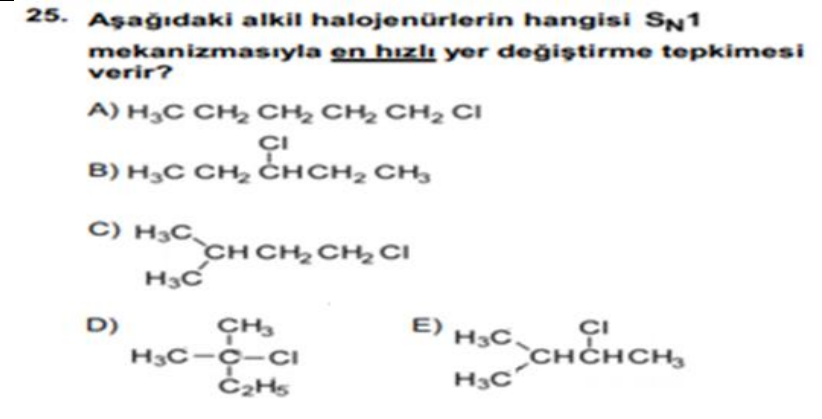 & $\begin{array}{l}\text { İsim Kısmı: Alkil halojenürlerin } \mathrm{S}_{\mathrm{N}}{ }^{1} \\
\text { mekanizmasıyla en hızlı yer değiş̧irme } \\
\text { tepkimesi } \\
\text { Fiil Kısmı: Verir? } \\
\text { Bilişsel Süreç Boyutu: } 5 \\
\text { Alt Basamağı: } 1 \\
\text { Bilgi Boyutu: D } \\
\text { Alt Basamağı: B } \\
\text { YBT Tablosunda Yeri: D5 } \\
\text { YBT Tablosunda Gösterimi: K/25/DB/51 }\end{array}$ \\
\hline $\begin{array}{l}\text { lklama: } \\
\text { cuda öğretmen adaylarının } \mathrm{S}_{\mathrm{N}}^{1} \text { tepkime mekanizma } \\
\text { gulanmaktadır. Öğretmen adayları, verilen alkil hr } \\
\text { ojenürü bulabilmeleri için seçeneklerdeki alkil halo } \\
\text { irlemeleri, indüktif etki vb. karbokatyonların kararl } \\
\text { hangi karbokatyonunun diğerlerine göre daha karar } \\
\text { eç düzeyinin "Değerlendirme" düzeyin alt basamağı } \\
\text { gi düzeyi için "Üstbilişsel bilgi" düzeyin alt basan } \\
\text { ünüldüğünden taksonomi tablosunda D5'e yerleştiri }\end{array}$ & $\begin{array}{l}\text { halojenürlerin yapı etkisi ile ilgili bilgileri } \\
\text { rden en hızlı } \mathrm{S}_{\mathrm{N}}^{1} \text { tepkimesini verecek alkil } \\
\text { tek tek inceleyerek oluşacak karbokatyonları } \\
\text { ileyecek etkileri göz önünde bulundurmaları } \\
\text { u tespit etmeleri gerekir. Bu yüzden bilişsel } \\
\text { yapma" olarak uygun görülmüşsür. Sorunun } \\
\text { " "Bilişsel görevlerle ilgili bilgi" basamağı } \\
\text { /25/DB/51 şeklinde gösterilmiştir. }\end{array}$ \\
\hline
\end{tabular}

Şekil 6. 2015 Kimya ÖABT'deki 25. sorunun YBT'ye göre analizi

\section{Geçerlilik ve Güvenilirlik}

Araştırmada geçerlilik ve güvenilirlik çalışmasının yapılması çalışmanın inandırıcılığını artırmakta değerlidir. Araştırmacının veri toplama araçlarından topladığı verileri ayrıntılı şekilde sunması ve bulgulardan ulaştığı sonuçları açıklaması iç ve dış geçerlilik için önemlidir. İç geçerlilik araştırmacının araştırma verilerini toplaması ve analiz sürecinde tutarlı olmasıyla ilgili olurken, dış geçerlilik, araştırmada ulaşılan sonuçlarının genellenebilir oluşuyla ilgilidir. Güvenilirlik analizi sonucunda birden fazla araştırmacı tarafından aynı olgunun ölçülmesi, yapılan analizlerin ayrıntılı olarak belirtilmesi ve verilerin yorumlanmadan önce olduğu gibi sunulmasıdır. İç güvenilirlik aynı verileri kullanarak araştırmacının sonuçlarına diğer araştırmacıların ulaşmasındaki tutarlılık olarak ifade edilirken dış güvenilirlik araştırmada elde edilen sonuçların birbiriyle benzer ortam veya şartlarda ulaşılan sonuçlara benzerlik göstermesidir (Başkale, 2016; Büyüköztürk, 2015; Yıldırım \& Şimşek, 2013).

$\mathrm{Bu}$ araştırmada kullanılan dokümanların nasıl temin edildiği, şablonun neden ve nasıl hazırlandığı ile ilgili gerekli bilgiler verilerin toplanması bölümünde detaylı şekilde açıklandığı için araştırmanın iç geçerliliğinin sağlandığ söylenebilir. Araştırmada doküman incelemesinin neden yapıldığı, bilişsel süreç düzeyleri belirlenirken nelerle karşılaşıldığ 1 ve analizin nasıl yapıldığ 1 hakkında tüm bilgiler ilgili bölümlerde ayrıntılı açıklandığı için dış geçerliliğin de sağlandığı söylenebilir. Hazırlanan şablona göre toplanan tüm veriler, yapılan yorumlar ve YBT'de düzeylerin çakıştığı yerler Organik Kimya ve Eğitim Bilimleri alanında uzman iki öğretim üyesinin görüssleri doğrultusunda gerekli düzeltmeler yapıldığı için iç güvenilirliğin sağlandığg düşünülmektedir. Elde edilen bulguların araştırma sonuçlarıyla karşılaştırmak için uzman görüşünün alınması araştırmanın dış güvenilirliğinin sağlandığ1 söylenebilir. Nitel araştırmalarda araştırmanın geçerliliği ve güvenilirliğinin artmasında uzman görüşleri önemlidir (Cansız Aktaş, 2014).

\section{BULGULAR}

Araştırmanın amacına uygun olarak hazırlanan şablon (Ek 1) göre sorularının analiz edilmiş ve elde edilen bulgular alt problemlere göre tablolar halinde verilmiştir.

\section{Birinci Alt Problemle İlgili Bulgular}

2013-2019/ÖABT'deki Organik Kimya sorularının YBT'ye göre bilişsel süreç ve bilgi düzeyleri aşağıdaki Tablo 5-10'da verilmiştir. 
Tablo 5 .

2013/ÖABT organik kimya sorularının YBT'ye göre dağılımı

\begin{tabular}{|c|c|c|c|c|c|c|}
\hline \multirow{2}{*}{ Olgusal Bilgi } & Hatırlama & Anlama & Uygulama & Çözümleme & Değerlendirme & Yaratma \\
\hline & $\mathrm{K} / 23 / \mathrm{AB} / 12$ & $\begin{array}{l}\mathrm{F} / 24 / \mathrm{AB} / 26 \\
\mathrm{~K} / 28 / \mathrm{AB} / 22\end{array}$ & & & & $\mathrm{~K} / 30 / \mathrm{AB} / 11$ \\
\hline Kavramsal & & $\mathrm{F} / 25 / \mathrm{BA} / 22$ & $\mathrm{~F} / 23 / \mathrm{BB} / 32$ & & & \\
\hline Bilgi & & $\mathrm{K} / 21 / \mathrm{BC} / 22$ & & & & \\
\hline & & $\mathrm{K} / 22 / \mathrm{BC} / 26$ & & & & \\
\hline & & $\mathrm{K} / 24 / \mathrm{BC} / 22$ & & & & \\
\hline & & $\mathrm{K} / 26 / \mathrm{BB} / 26$ & & & & \\
\hline & & $\mathrm{K} / 29 / \mathrm{BA} / 26$ & & & & \\
\hline İșlemsel Bilgi & & & & & & \\
\hline Üstbilişsel Bilgi & & & & & $\mathrm{K} / 27 / \mathrm{DB} / 51$ & K/25/61/DB \\
\hline
\end{tabular}

2013/ÖABT'deki Organik Kimya sorularının YBT'ye göre bilişsel süreç düzeylerindeki dağılımları "Hatırlama", "Uygulama" ve "Değerlendirme" düzeylerinde 1'er, "Anlama" düzeyinde 8, "Yaratma" düzeyinde 2 soru bulunurken "Çözümleme" düzeyinde soru bulunmamaktadır. Soruların bilgi düzeyleri sirasıyla 4'ü "Olgusal”, 7'si "Kavramsal” ve 2'si “Üstbilişsel bilgi” düzeyinde olurken "İşlemsel” bilgi düzeyinde olmadığı belirlenmiştir (Tablo 5).

Tablo 6.

2014/ÖABT organik kimya sorularının YBT' ye göre dă̆llımı

\begin{tabular}{|c|c|c|c|c|c|c|}
\hline \multirow{3}{*}{ Olgusal Bilgi } & Hatırlama & Anlama & Uygulama & Çözümleme & Değerlendirme & Yaratma \\
\hline & $\mathrm{F} / 25 / \mathrm{AB} / 12$ & F/24/AB22 & & & & \\
\hline & K/30/AB12 & $\mathrm{K} / 27 / \mathrm{AB} / 21$ & & & & \\
\hline & & $\mathrm{K} / 21 \mathrm{AB} / 22$ & & & & \\
\hline Kavramsal & & $\mathrm{K} / 24 / \mathrm{BC} / 22$ & $\mathrm{~K} / 23 / \mathrm{BC} / 32$ & & & \\
\hline \multirow[t]{3}{*}{ Bilgi } & & $\mathrm{K} / 22 / \mathrm{BC} / 26$ & & & & \\
\hline & & $\mathrm{K} / 28 / \mathrm{BB} / 26$ & & & & \\
\hline & & $\mathrm{K} / 29 / \mathrm{BB} / 24$ & & & & \\
\hline \multicolumn{7}{|l|}{ İșlemsel Bilgi } \\
\hline Üstbilişsel Bilgi & & & & & & $\begin{array}{l}\mathrm{K} / 25 / \mathrm{DB} / 61 \\
\mathrm{~K} / 26 / \mathrm{DB} / 61\end{array}$ \\
\hline
\end{tabular}

2014/ÖABT'deki Organik Kimya sorularının YBT'ye göre bilişsel süreç düzeylerindeki dağılımları "Hatırlama" ve "Yaratma" düzeylerinde 2'şer, "Anlama" düzeyinde 7, "Uygulama" düzeyinde 1 soru bulunurken "Çözümleme" ve "Değerlendirme" düzeylerinde bulunmadığ belirlenmiştir. Soruların bilgi düzeylerindeki dağılım sırasıyla "Olgusal" ve "Kavramsal" bilgi düzeyinde 5'er, "Üstbilişsel" bilgi düzeyinde 2 soru bulunurken "İşlemsel bilgi düzeyinde soru bulunmamaktadır (Tablo 6).

Tablo 7.

2015/ÖABT organik kimya sorularının YBT'ye göre dağılımı

\begin{tabular}{|c|c|c|c|c|c|c|}
\hline . & Hatırlama & Anlama & Uygulama & Çözümleme & Değerlendirme & Yaratma \\
\hline Olgusal Bilgi & $\mathrm{F} / 25 / \mathrm{AB} / 12$ & $\begin{array}{l}\mathrm{F} / 24 / \mathrm{AB} / 22 \\
\mathrm{~K} / 21 / \mathrm{AB} / 22\end{array}$ & & & & \\
\hline Kavramsal Bilgi & $\mathrm{K} / 28 / \mathrm{BB} / 12$ & $\begin{array}{l}\mathrm{K} / 12 / \mathrm{BC} / 26 \\
\mathrm{~K} / 22 / \mathrm{BC} / 26 \\
\mathrm{~K} / 23 / \mathrm{BC} / 22 \\
\mathrm{~K} / 24 / \mathrm{BC} / 22 \\
\mathrm{~K} / 30 / \mathrm{BC} / 22\end{array}$ & & & & \\
\hline $\begin{array}{l}\text { İşlemsel Bilgi } \\
\text { Üstbilişsel Bilgi }\end{array}$ & & & & & $\begin{array}{l}\mathrm{K} / 25 / \mathrm{DB} / 51 \\
\mathrm{~K} / 26 / \mathrm{DB} / 51\end{array}$ & $\begin{array}{l}\mathrm{K} / 27 / \mathrm{DB} / 61 \\
\mathrm{~K} / 29 / \mathrm{DB} / 61\end{array}$ \\
\hline
\end{tabular}

2015/ÖABT Organik Kimya sorularının YBT' ye göre bilişsel süreç düzeylerindeki dağılımları "Hatırlama", "Değerlendirme" ve "Yaratma" düzeylerinde 2'şer "Anlama" düzeyinde 7 soru bulunurken, "Çözümleme" düzeyinde bulunmamaktadır. Soruların bilgi düzeyleri "Olgusal" 3; "Kavramsal" 6 ve "Üstbilişsel" bilgi düzeyinde 4 soru bulunurken, "İşlemsel" bilgi düzeyinde soru bulunmamaktadır (Tablo 7). 
Tablo 8.

2016/ÖABT organik kimya sorularının YBT'ye göre dağılımı

\begin{tabular}{llllll}
\hline \multicolumn{1}{c}{ Olgusal Bilgi } & Hatırlama & Anlama & Uygulama & Çözümleme Değerlendirme & Yaratma \\
& F/25/AA/11 & K/22/AB/22 & & \\
& $\mathrm{K} / 20 / \mathrm{AA} / 11$ & & & \\
& $\mathrm{~K} / 25 / \mathrm{AA} / 11$ & & & \\
Kavramsal Bilgi & $\mathrm{K} / 21 / \mathrm{BB} / 11$ & $\mathrm{~K} / 23 / \mathrm{BA} / 25$ & & \\
& & $\mathrm{~K} / 24 / \mathrm{BC} / 26$ & & \\
& & $\mathrm{~K} / 26 / \mathrm{BC} / 22$ & & \\
& & $\mathrm{~K} / 28 / \mathrm{BA} / 21$ & & \\
& & $\mathrm{~K} / 29 / \mathrm{BA} / 26$ & & \\
İşlemsel Bilgi & & $\mathrm{K} / 30 / \mathrm{BC} / 26$ & $\mathrm{~K} / 27 / \mathrm{DB} / 61$ \\
\hline
\end{tabular}

2016/ÖABT Organik Kimya sorularının YBT' ye göre bilişsel süreç düzeylerinde dağılımları "Hatırlama" 5, "Anlama", 7 "Yaratma" düzeyinde 1 soru bulunurken "Uygulama", "Çözümleme" ve "Değerlendirme" düzeylerinde soru bulunmamaktadır. Soruların bilgi düzeylerindeki dağılımları "Olgusal" 5, "Kavramsal" 7 ve "Üstbilişsel" bilgi düzeyinde 1 soru bulunurken "İşlemsel bilgi" düzeyinde bulunmamaktadır (Tablo 8).

Tablo 9.

2017/ÖABT organik kimya sorularının YBT'ye göre dağılımı

\begin{tabular}{|c|c|c|c|c|c|c|}
\hline & Hatırlama & Anlama & Uygulama & Çözümleme & Değerlendirme & Yaratma \\
\hline \multirow[t]{3}{*}{ Olgusal Bilgi } & $\mathrm{F} / 24 / \mathrm{AB} / 12$ & $\mathrm{~F} / 25 / \mathrm{AB} / 26$ & & & & \\
\hline & $\mathrm{K} / 29 / \mathrm{AB} / 12$ & $\mathrm{~K} / 21 / \mathrm{AB} / 24$ & & & & \\
\hline & & $\mathrm{K} / 30 / \mathrm{AB} / 26$ & & & & \\
\hline Kavramsal Bilgi & & $\mathrm{K} / 21 / \mathrm{BC} / 26$ & $\mathrm{~K} / 23 / \mathrm{BC} / 32$ & & & \\
\hline & & $\mathrm{K} / 28 / \mathrm{BC} / 26$ & & & & \\
\hline \multicolumn{7}{|l|}{ İşlemsel Bilgi } \\
\hline Üstbilişsel bilgi & & & & & $\mathrm{K} / 24 / \mathrm{DB} / 51$ & $\mathrm{~K} / 25 / \mathrm{DB} / 61$ \\
\hline
\end{tabular}

2017/ÖABT Organik Kimya sorularının YBT'ye göre, bilişsel süreç düzeylerindeki dağılımları "Hatırlama", Değerlendirme" ve "Yaratma" düzeylerinde 2'şer, "Anlama" düzeyinde 5 "Uygulama" düzeyinde 1, soru bulunurken "Çözümleme" düzeyinde bulunmamaktadır. Soruların bilgi düzeylerindeki dağılımları sırasıyla, "Olgusal" 5, "Kavramsal" 3 ve "Üstbilişsel" düzeyinde 4 soru bulunurken "İ̧̧lemsel" bilgi düzeyde bulunmamaktadır (Tablo 9).

Tablo 10.

2018 ve 2019/ÖABT organik kimya sorularının YBT'ye göre dağılımı

\begin{tabular}{llllll}
\hline & Hatırlama & Anlama & Uygulama Çözümleme & Değerlendirme & Yaratma \\
\hline Olgusal Bilgi & F/24/AA/11 & $\mathrm{K} / 40 / \mathrm{AB} / 22$ & & & \\
Kavramsal Bilgi & & $\mathrm{K} / 28 / \mathrm{BC} / 22$ & & \\
İşlemsel Bilgi & & & & \\
Üstbilişsel Bilgi & & & & \\
\hline
\end{tabular}

2018 ve 2019/ÖABT'lerde \%10'u yayınlanan sorulardan Organik Kimya sorularının bilişsel süreç düzeyleri 2018'de Hatırlama" ve "Anlama” düzeylerinde 1'er soru bulunurken 2019'da Anlama düzeyinde 1 soru bulunmaktadır. Soruların bilgi düzeyleri 2018'deki iki sorunun biri "Olgusal" diğeri "Kavramsal" bilgi düzeyi olurken 2019'daki bilişsel süreç düzeyi "Anlama" olan soru "Olgusal" bilgi düzeyindedir (Tablo 10).

\section{İkinci Alt Problemle İlgili Bulgular}

2013-2019/ÖABT'deki Organik Kimya sorularının YBT’ye göre bilişsel süreç düzeylerinin yıllara göre dağılımı Tablo 11'de verilmiştir. 
Tablo 11.

2013-2019/ÖABT organik kimya sorularının bilişsel süreç düzeylerinin yıllara göre dağılımı

\begin{tabular}{|c|c|c|c|c|c|c|c|c|c|c|c|c|c|c|}
\hline \multirow{2}{*}{$\begin{array}{l}\text { Bilişsel Süreç } \\
\text { Boyutu }\end{array}$} & \multicolumn{2}{|c|}{2013} & \multicolumn{2}{|c|}{2014} & \multicolumn{2}{|c|}{2015} & \multicolumn{2}{|c|}{2016} & \multicolumn{2}{|c|}{2017} & \multicolumn{4}{|c|}{2018 ve 2019 Toplam } \\
\hline & $\mathrm{f}$ & $\%$ & $\mathrm{f}$ & $\%$ & $\mathrm{f}$ & $\%$ & $\mathrm{f}$ & $\%$ & $\mathrm{f}$ & $\%$ & $\mathrm{f}$ & $\%$ & $\mathrm{f}$ & $\%$ \\
\hline Hatırlama & 1 & 7,7 & 2 & 16,7 & ! & 5,4 & 5 & 38,5 & 2 & 16,7 & 1 & $?$ & 13 & 19,7 \\
\hline Anlama & 8 & 61,5 & 7 & 58,3 & ' & $i 3,8$ & 7 & 53,8 & 5 & 41,6 & 2 & $?$ & 36 & 54,6 \\
\hline $\begin{array}{l}\text { Uygulama } \\
\text { Çözümleme }\end{array}$ & 1 & 7,7 & 1 & 8,3 & & & & & 1 & 8,3 & & & 3 & 4,5 \\
\hline Değerlendirme & 1 & 7,7 & & & : & 5,4 & & & 2 & 16,7 & & & 5 & 7,6 \\
\hline Yaratma & 2 & 15,4 & 2 & 16,7 & $!$ & 5,4 & 1 & 7,7 & 2 & 16,7 & & & 9 & 13,6 \\
\hline Toplam & 13 & 100 & 12 & 100 & 3 & 00 & 13 & 100 & 12 & 100 & 3 & $?$ & 66 & 100 \\
\hline
\end{tabular}

Tablo 11'de soruların bilişsel süreç düzeyleri azdan çoğa doğru sıralandığında "Uygulama" $(\%, 4,5)$, "Değerlendirme" $(\% 7,6)$, "Yaratma" $(\% 13,6)$, "Hatırlama" $(\% 19,7)$ ve "Anlama" $(\% 54,6)$ düzeylerinde soru olurken "Çözümleme" düzeyinde soru bulunmamaktadır.

\section{Üçüncü Alt Problemle İlgili Bulgular}

2013-2019/ÖABT'deki Organik Kimya sorularının YBT'ye göre bilgi düzeylerinin yıllara göre dağılımı Tablo 12'de verilmiştir.

Tablo 12.

2013-2019/ÖABT organik kimya sorularının bilgi düzeylerinin yıllara göre dağıllımı

\begin{tabular}{|c|c|c|c|c|c|c|c|c|c|c|c|c|c|c|}
\hline \multirow[t]{2}{*}{ Bilgi Boyutu } & \multicolumn{2}{|c|}{2013} & \multicolumn{2}{|c|}{2014} & \multicolumn{2}{|c|}{2015} & \multicolumn{2}{|c|}{2016} & \multicolumn{2}{|c|}{2017} & \multicolumn{4}{|c|}{2018 ve 2019 Toplam } \\
\hline & $\mathrm{f}$ & $\%$ & f & $\%$ & $\mathrm{f}$ & $\%$ & $\mathrm{f}$ & $\%$ & $\mathrm{f}$ & $\%$ & $\mathrm{f}$ & $\%$ & $\mathrm{f}$ & $\%$ \\
\hline Olgusal Bilgi & 4 & 30,7 & 5 & 41,7 & ; & $: 3,1$ & 5 & 38,5 & 4 & 33,3 & 2 & $?$ & 23 & 34,8 \\
\hline $\begin{array}{l}\text { Kavramsal Bilgi } \\
\text { İşlemsel Bilgi }\end{array}$ & 7 & 53,8 & 5 & 41,7 & ; & $\vdash 6,1$ & 7 & 53,8 & 4 & 33,3 & 1 & $?$ & 30 & 45,5 \\
\hline Üstbilişsel Bilgi & 2 & 15,4 & 2 & 16,7 & t & 30,8 & 1 & 7,7 & 4 & 33,3 & & & 13 & 19,7 \\
\hline Toplam & 13 & 100 & 12 & 100 & 13 & 100 & 13 & 100 & 12 & 100 & 2 & $?$ & 66 & 100 \\
\hline
\end{tabular}

Tablo 12'de soruların bilgi düzeyleri azdan çoğa doğru dağılımı sırasıyla "Üstbilişsel”, (\%19,7), "Olgusal” $(\% 34,8)$ ve "Kavramsal” $(\% 45,5)$ bilgi düzeyinde değişirken "İ̧slemsel” bilgi düzeyinde soru bulunmamaktadır.

\section{Dördüncü Alt Problemle İlgili Bulgular}

2013-2019/ÖABT'deki Organik Kimya sorularının YBT'ye göre bilişsel süreç düzeylerinin alt basamaklarının yıllara göre dağılımı Tablo 13'de verilmiştir.

Tablo 13.

2013-2019/ÖABT organik kimya sorularının bilişsel süreç düzeylerinin alt basamaklarının yıllara göre dağılımı

\begin{tabular}{|c|c|c|c|c|c|c|c|c|c|c|c|c|c|c|c|}
\hline \multirow{2}{*}{$\begin{array}{l}\text { Bilimsel } \\
\text { Süreç } \\
\text { Düzeyi }\end{array}$} & \multirow{2}{*}{$\begin{array}{l}\text { Alt } \\
\text { Basamağ1 }\end{array}$} & \multicolumn{2}{|c|}{2013} & \multicolumn{2}{|c|}{2014} & \multicolumn{2}{|c|}{2015} & \multicolumn{2}{|c|}{2016} & \multicolumn{2}{|c|}{2017} & \multicolumn{2}{|c|}{$2018-2019$} & \multicolumn{2}{|c|}{ Toplam } \\
\hline & & f & $\%$ & $\mathrm{f}$ & $\%$ & $\mathrm{f}$ & $\%$ & $\mathrm{f}$ & $\%$ & f & $\%$ & $\mathrm{f}$ & $\%$ & $\mathrm{f}$ & $\%$ \\
\hline$\overline{1}$ & 1 & & & & & & & 5 & 38,5 & & & 1 & ? & 6 & 9,1 \\
\hline & 2 & 1 & 7,7 & 2 & 16,7 & 1 & 7,7 & & & 2 & 16,7 & & & 6 & 9,1 \\
\hline 2 & 1 & & & 1 & 8,3 & & & 1 & 7,7 & & & & & 2 & 3,0 \\
\hline & $\begin{array}{l}2 \\
3\end{array}$ & 4 & 30,7 & 3 & 25,0 & 5 & 38,5 & 2 & 15,4 & & & 2 & $?$ & 16 & 24,2 \\
\hline & 4 & & & 1 & 8,3 & & & & & 1 & 8,3 & & & 2 & 3,0 \\
\hline & 5 & & & & & & & 1 & 7,7 & & & & & 1 & 1,5 \\
\hline & $\begin{array}{l}6 \\
7\end{array}$ & 4 & 30,7 & 2 & 16,7 & 2 & 15,4 & 3 & 23,1 & 4 & 33,3 & & & 15 & 22,7 \\
\hline 3 & 1 & & & & & & & & & & & & & & \\
\hline & 2 & 1 & 7,7 & 1 & 8,3 & 1 & 7,7 & & & 1 & 8,3 & & & 4 & 6,0 \\
\hline 4 & $\begin{array}{l}1 \\
2 \\
3\end{array}$ & & & & & & & & & & & & & & \\
\hline 5 & 1 & 1 & 7,7 & & & 2 & 15,4 & & & 2 & 16,7 & & & 5 & 7,6 \\
\hline
\end{tabular}




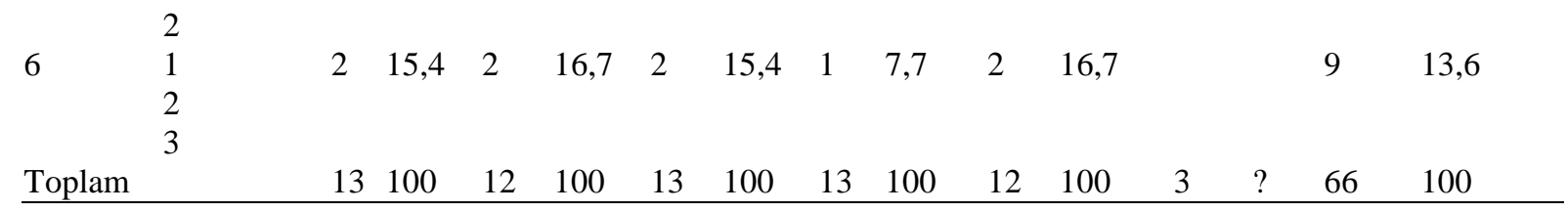

Soruların bilişsel süreç düzeylerindeki alt basamaklarının yıllara göre en fazla dağılımları "Hatırlama" düzeyinde "Tanıma/Fark etme" (\%9,1), "Anlama" düzeyinde "Örnekleme" $(\% 24,2)$ ve "Karş1laştırma" (\%22,7), "Uygulama" düzeyinde "Kullanma" (\%6,0), "Değerlendirme" düzeyinde "Denetim yapma" $(\% 7,6)$ ve "Yaratma" düzeyinde "Oluşturma" $(\% 13,6)$ basamaklarında olurken "Çözümleme" düzeyinin alt basamaklarında soru bulunmamaktadır (Tablo 13).

\section{Beşinci Alt Problemle İlgili Bulgular}

2013-2019/ÖABT'deki Organik Kimya sorularının YBT'ye göre bilgi düzeylerinin alt basamaklarının yıllara göre dağılımı Tablo 14'de verilmiştir.

Tablo 14.

ÖABT organik kimya sorularının bilgi düzeylerinin alt basamaklarının ylllara göre frekans ve yüzde dăgılımı

\begin{tabular}{|c|c|c|c|c|c|c|c|c|c|c|c|c|c|c|c|}
\hline \multirow{2}{*}{$\begin{array}{l}\text { Bilgi } \\
\text { Boyutu }\end{array}$} & \multirow{2}{*}{$\begin{array}{l}\text { Alt } \\
\text { Basamağ }\end{array}$} & \multicolumn{2}{|c|}{2013} & \multicolumn{2}{|c|}{2014} & \multicolumn{2}{|c|}{2015} & \multicolumn{2}{|c|}{2016} & \multicolumn{2}{|c|}{2017} & \multicolumn{4}{|c|}{2018 ve 2019 Toplam } \\
\hline & & $f$ & $\%$ & $\mathrm{f}$ & $\%$ & $\mathrm{f}$ & $\%$ & $\mathrm{f}$ & $\%$ & $\mathrm{f}$ & $\%$ & $f$ & $\%$ & $\mathrm{f}$ & $\%$ \\
\hline & A & & & & & & & 4 & 30,7 & 1 & 8,3 & 1 & $?$ & 6 & 9,1 \\
\hline A & B & 4 & 31,8 & 5 & 41,6 & 3 & 23,1 & 1 & 7,7 & 4 & 33,3 & 1 & $?$ & 18 & 27,3 \\
\hline & A & 2 & 15,4 & & & & 7,7 & 3 & 23,1 & & & & & 5 & 7,6 \\
\hline B & B & 2 & 15,4 & 2 & 16,7 & 1 & 38,5 & 1 & 7,7 & & & & & 6 & 9,1 \\
\hline & $\begin{array}{l}\mathrm{C} \\
\mathrm{A}\end{array}$ & 3 & 23,1 & 3 & 25,0 & 5 & & 3 & 23,1 & 3 & 25,0 & 1 & $?$ & 18 & 27,3 \\
\hline $\mathrm{C}$ & $\begin{array}{l}\text { B } \\
\text { C } \\
\text { A }\end{array}$ & & & & & & & & & & & & & & \\
\hline $\mathrm{D}$ & $\begin{array}{l}\text { B } \\
\text { C }\end{array}$ & 2 & 15,4 & 2 & 16,7 & 4 & 30,7 & 1 & 7,7 & 4 & 33,3 & & & 13 & 19,7 \\
\hline Toplam & & 13 & 100 & 12 & 100 & 13 & 100 & 13 & 100 & 12 & 100 & 3 & $?$ & 66 & 100 \\
\hline
\end{tabular}

Soruların bilgi düzeylerindeki alt basamaklarının yıllara göre en fazla dağılımı "Olgusal bilgi" düzeyinde "Özel detay ve öğeler bilgisi" (\%27,3), "Kavramsal bilgi” düzeyinde "Teoriler, modeller ve yapılar bilgisi" (\%27,3) ve "Üstbilişsel bilgi" düzeyinde "Bilişsel görevlerle ilgili bilgi" $(\% 19,7)$ basamaklarında olurken "Işslemsel bilgi" düzeyinin alt basamaklarında soru bulunmaktadır (Tablo 14).

\section{TARTIŞMA, SONUÇ ve ÖNERILER}

2013-2019/ÖABT'lerdeki Organik Kimya sorularının YBT’ye göre analizi sonucunda bilişsel süreç düzeylerinden "Hatırlama" düzeyinde en fazla soru 2016'da en az 2013'de sorulmuştur. "Anlama" düzeyinde tüm testlerde soru dağılımı neredeyse birbirine yakın olsa da en az 2017'de olduğu söylenebilir. "Uygulama" düzeyinde sadece 2013 ve 2017 'de birer soru bulunurken diğer y1llarda bulunmamaktadır. "Değerlendirme" düzeyinde 2013, 2015 ve 2017'de soru bulunurken 2014 ve 2016 'da bulunmamaktadır. "Yaratma" düzeyinde hemen hemen her yıl bir ya da iki soru bulunduğu, en az 2016'da olduğu görülebilir (Tablo 11). Genel olarak bakıldığında soruların bilişsel süreç düzeylerinin alt bilişsel süreç düzeylerinde daha fazla olduğu ve düzeylerin belli başlı alt basamaklarında yoğunlaştığı söylenebilir. (Tablo 13). Örneğin, Hatırlama" düzeyinde "Tanıma/Fark etme", "Özel detay ve öğeler bilgisi, "Anlama" düzeyinde "Örnekleme ve "Karşılaştırma", "Değerlendirme" düzeyinde "Denetim Yapma", "Yaratma" düzeyinde "Oluşturma" basamaklarındaki soruların diğer alt basamaklara göre daha fazla olduğu görülebilir. Bu durum soruların bilişsel süreç düzeylerinin belli alt basamaklarda yoğunlaştığını ve belli başlı konuların (organik bileşiklerin 
adlandırılması, yapı izomeri kavramı, asitlik bazlık karşılaştırılması vb.) hemen hemen aynı bilişsel süreç düzeyinde sorulduğunu bundan sonra yapılacak sınavlarda da benzer olacağını düşündürmektedir.

Soruların bilgi düzeylerinin yıllara göre dağılımı "Olgusal bilgi” düzeyinde en fazla soru 2016' da olurken en az 2015'de olduğu söylenebilir. "Kavramsal bilgi” düzeyde en fazla 2013 ve 2016'da olurken en az 2017'de sorulmuştur. "Üstbilişsel" düzeyde en fazla 2015 ve 2017 'de, en az 2016'da olduğu görülebilir (Tablo 12). Soruların bilgi düzeylerininin alt basamaklarının dağılımı (Tablo 14) bilişsel süreç düzeylerinde olduğu gibi belli başlı alt basamaklarda yoğunlaştığı söylenebilir. Örneğin "Olgusal bilgi" düzeyinde "Özel detay ve öğeler bilgisi", "Kavramsal bilgi" düzeyinde "Teoriler, modeller ve yapılar bilgisi" ve "Üstbilişsel bilgi" düzeyinde "Bilişsel görevlerle ilgili bilgi" basamaklarında yoğunlaşırken "İşlemsel bilgi" düzeyindeki alt basamaklarda sorunun olmaması organik Kimya dersinin içeriğinde işlem gerektiren konuların fazla olmamasından kaynaklandığını düşündürmektedir.

Soruların bilişsel süreç ve bilgi düzeylerindeki dağılımlarına genel olarak bakıldığında literatürdeki diğer araştırmacıların yapmış olduğu çalışmaların sonuçlarına benzerlik gösterdiği söylenebilir. Örneğin Korkmaz \& Ünsal (2015), 2013'deki Tarih ÖABT'deki soruların çoğunluğunun (\%94) alt bilişsel düzeylerde olduğunu belirtirken üstbilişsel süreç düzeyinde çok az (\%6) olduğunu, alt bilişsel düzeydeki soruların "Hatırlama" (\%62), "Anlama" (\%24) ve "Uygulama" (\%8) düzeylerinde olduğunu ifade etmişlerdir. Araştırmacılar üstbilişsel süreç düzeyinde "Çözümleme" ve "Yaratma" düzeylerinde (\%2) soru bulunurken "Değerlendirme" düzeyinde bulunmadığını açıklamışlardır. Benzer şekilde araştırmacılar bilgi düzeylerindeki sorularının dağılımı için "Olgusal bilgi” (\%62), "Kavramsal bilgi” (\%24), "İşlemsel bilgi” (\%12) ve "Üstbilişsel bilgi” (\%2) şeklinde açıklamışlardır. Karaer (2019), KPSS/ÖABT'lerindeki Analitik Kimya ile ilişkili 83 soruyu analiz ettiği çalışmasında soruların bilişsel süreç düzeylerinin alt bilişsel düzeylerde yoğunlaştı̆̆ını (\%8,4 "Hatırlama", \%25,6 "Anlama", \%50 "Uygulama") üstbilişsel düzeylerde sadece \%14,6 "Çözümleme" düzeylerinde soru bulunduğunu, "Değerlendirme" ve "Yaratma" düzeylerinde soru bulunmadığını belirtmiştir. Araştırmacı soruların bilgi düzeylerinin sirasıly \%7,2 "Olgusal bilgi”, \%31,3 "Kavramsal bilgi”, \%61,5 "İ̧̧lemsel bilgi" düzeylerde olduğunu belirtirken "Üstbilişsel bilgi" düzeyinde soru olmadığını açıklamıştır. Aynı zamanda araştırmacı soruların bilişsel süreç düzelerinden "Uygulama", bilgi düzeylerinden "İşlemsel bilgi" düzeyinde daha çok soru olmasını Analitik Kimya dersinin içeriğinde problemlerin fazla olmasından kaynaklanabileceğini ifade etmiştir. Topçu (2017), TEOG sınavlarındaki Tarihle ilişkili 160 soruyu YBT'ye göre analiz ettiğinde soruların "Anlama" (\%89), "Hatırlama" (\%8,1), "Çözümleme" $(\% 2,5)$ düzeylerinde olduğunu ve alt bilişsel düzeyde yoğunlaştı̆̆ını tespit etmiştir. Şanlı ve Pınar (2017), Sosyal bilgiler dersi sınav sorularını YBT'ye göre analiz ettiklerinde bilişsel süreç boyutunun "Değerlendirme" ve "Oluşturma" basamaklarında soru sayısının çok az olduğunu belirtmişlerdir.

Akanngbe \& Enero (2015), Nijerya'da farklı kimya ders kitaplarının bölüm sonu sorularını sınıflandırmak ve analiz etmek için YBT'den yararlandıkları çalışmada soruların çoğunluğunun (\%76) alt bilişsel düzeyde ("Hatırlama", "Anlama", "Uygulama") olduğunu, bilgi düzeylerinin "Kavramsal bilgi" (\%46) ve "Iş̧lemsel bilgi" düzeyde (\%32) yoğunlaştı̆̆ını belirtmişlerdir. Ayrıca araştırmacılar "Değerlendirme" ve "Yaratma" kategorilerindeki soru sayısının bilişsel süreç becerilerinin diğer kategorilerden önemli ölçüde farklılık gösterdiğini ve farklılı̆̆ın $p<0,01$ düzeyinde anlamlı olduğunu belirtmişlerdir. İlave olarak araştırmacılar en fazla soru "Anlama" ve "Çözümleme" düzeylerinde olurken "Üstbilişsel" düzeyde soru olmadığını açıklamışlardır. Tikkanen \& Aksela (2012), Finlandiya' da üniversite sınavındaki kimya sorularını YBT'ye göre analiz ettiklerinde üstbilişsel süreç düzeyindeki soruların çoğunlukta (\%77) olduğunu, ancak "Çözümleme", "Değerlendirme" ve "Yaratma" düzeylerine eşit dağılmadığını belirtmişlerdir.

Akçay, Akçay \& Kahramanoğlu (2017), ortaokul fen bilimleri öğretim programlarına göre hazırlanan ders kitaplarının çoğunluğunun altbilişsel düzeyde soruları içerdiğini ve üstbilişsel süreç becerilerinin gelişmesini olumsuz etkileceyecininin kaçınılmaz olduğunu ifade etmişlerdir. Ayvacı \& Şahin (2009), fen bilgisi öğretmenlerinin dersteki sorularının bilişsel düzeylerinin ezbere öğrenmeyi teşvik ederken yazılı sınav sorularının daha üstbilişsel süreç düzeyinde olduğunu açıklamışlardır. Ayrıca öğretmenlerin yazılı soruları ile derste sordukları sorularının uyumlu olmadığını ve fen bilgisi ögretmenlerinin yazılı sınavlarında sordukları soruların yarısından fazlasının "Hatırlama" ve "Anlama" 
düzeylerinde olduğunu belirtmişlerdir. Dindar \& Demir (2006), beşinci sınıf fen bilimleri dersi öğretmenlerinin sınav sorularının bilişsel süreç düzeylerinin daha çok "Hatırlama" düzeyindeki soruları içerdiğini belirtmişlerdir. Tanık \& Saraçoğlu (2011), fen bilgisi dersi yazılı sınavlarındaki soruların öğrencilerin üstbilişsel düşünme becerilerini ölçecek nitelikten ziyade alt bilişsel süreç düzeyde olduğunu ve "Hatırlama" düzeyinde yoğunlaştığını açıklamışlardır. Güven \& Aydın (2015), sekizinci sınıf fen bilimleri öğretim programındaki 156 soruyu YBT'ye göre analiz ettiklerinde soruların $\% 12,18$ "Hatırlama", \%48,72 “Anlama”, \%13,46 "Uygulama", \%23,72 "Çözümleme" "Değerlendirme” \%0,64 ve "Yaratma" \%1,28 olduğunu belirtmişler.

Sonuç olarak, 2013-2019'daki KPSS-ÖABT'lerdeki sorulardan Organik Kimya sorularının yaklaşık beşte birinin üstbilişsel düzeyde olması soruların ayırt ediciliğinin düşük olduğunu ve nitelikli öğretmen adaylarının seçilme olasılığının düşük olacağını düşündürmektedir. Literatürde bu düşünceyi destekleyen çalışmalara rastlamak mümkündür. Örneğin, Taşan ve Bektaş (2016), fen bilgisi öğretmen adaylarının KPSS'nin nitelikli öğretmen adaylarını seçtiğini düşünmediklerini belirtmişlerdir. Şahin ve Demir (2016) Türkçe öğretmen adaylarının alan bilgisi testindeki soruların öğretmenlik yeterliliğini ölçecek düzeyde olmadığ 1 vb. olumsuz düşüncelere sahip olduklarını açıklamışlardır. Karaer, Karaer ve Kartal (2018), KPSS'ye girecek öğretmen adaylarının ÖABT'deki soruların adayların alan bilgisi düzeylerini ölçme olasıllı̆ının düşük olduğunu düşündüklerini belirtmişlerdir. Aynı zamanda bu araştırma literatürde OBT veya YBT'ye göre soru analiziyle ilgili yapılıış çalışmaların alanları farklı olsa da soruların bilişsel süreç ve bilgi düzeylerinin benzer olduğunu gösterdiği söylenebilir.

Ülkenin geleceğini şekillendirecek ve uzman olarak öğretmenlik mesleğinin gereğini yerine getirecek adayların seçiminde kullanılan ÖABT'lerdeki soruların ayırt ediciliğinin yüksek olması, konu ve kazanımları içerecek şekilde harmanlanması, sınav sorusu hazırlanırken birden fazla kazanımıma yönelik olmasına özen gösterilmesi, beli başlı konu ya da kazanımların yerine lisans programındaki Organik Kimya konularını kapsayacak şekilde soruların hazırlanması ve soruların bilişsel süreç düzeylerinin alt bilişsel ve üstbilişsel düzeylere mümkün olduğunca homojen dağıtılması önerilmektedir.

\section{KAYNAKÇA}

Akçay, E. Akçay, H., \& Kahramanoğlu, E. (2017). Ortaokul fen bilimleri ders kitaplarının Bloom taksonomisine göre incelenmesi. Uludă̆ Üniversitesi Eğitim Fakültesi Dergisi, 30(2), 521-549.

Akanngbe, J. M., \& Enero, U. J. (2015). Classification of end- of- chapter questions in senior school chemistry textbooks used in Nigeria. Electronic Journal of Science Education, 19(7), 1-16.

Amer, A. (2006). Reflections on Bloom's revised taxonomy. Electronic Journal of Research in Educational Psychology, 4(1), 231-230.

Anderson, L. W., \& Krathwohl, D. R. (2001). A taxonomy for learning, teaching and assessing: a revision of Bloom's taxonomy of educational objectives. New York: Longman.

Arseven, A., Şimşek, U., \& Güden, M. (2016). Coğrafya dersi yazılı sınav sorularının yenilenmiş Bloom taksonomisine göre analizi. Cumhuriyet Üniversitesi Sosyal Bilimler Dergisi, 40(1), 243-258.

Ayvacı, H.Ş., \& Şahin, Ş. (2009). Fen bilgisi öğretmenlerinin ders sürecinde ve yazılı sınavlarda sordurdukları soruların bilişsel seviyelerinin karşılaştırılması. Uludağ Üniversitesi Eğitim Fakültesi Dergisi, 22(2), 441455.

Ayvacı, H. Ş., \& Türkdoğan, A. (2010). Yeniden yapılandırılan Bloom taksonomisine göre fen ve teknoloji dersi yazılı sorularının incelenmesi. Türk Fen Eğitim Dergisi, 7(1),13-25.

Azar, A. (2005). Analysis of Turkish high school physics examination questions and university entrance exams questions according to Bloom' taxonomy. Türk Fen Eğitimi Dergisi, 2(2), 144-150.

Başkale, H. (2016). Nitel araştırmalarda geçerlik, güvenirlik ve örneklem büyüklüğünün belirlenmesi. Dokuz Eylül Üniversitesi Hemşirelik Fakültesi Elektronik Dergisi, 9(1), 23-28.

Beyrekli, L., \& Sönmez, H. (2017). Bloom taksonomisi ve yenilenmiş Bloom taksonomisi ile ilgili Türkiye'de yapılan çalışmaların odaklandığı araştırma konuları. International Journal of Languages' Education and Teaching, 5(2), 213-229.

Bümen, N.T. (2006). Program geliştirmede bir dönüm noktası. Yenilenmiş Bloom taksonomisi. Eğitim ve Bilim, 31(142),3-14.

Büyüköztürk, Ş. (2015). Bilimsel araştırma yöntemleri. (19. Baskı). Pegem Akademi Yayıncılık, Ankara. 
Cansız Aktaş, M. (2014). Nitel veri toplama araçlarl, eğitimde bilimsel araştırma yöntemleri. (Editör: M. Metin) Pegem Akademi, Ankara.

Çelikten, M., Şanal, M., \& Yeni, Y. (2005). Öğretmenlik mesleği ve özellikleri. Erciyes Üniversitesi, Sosyal Bilimler Enstitüsü Dergisi, 19 (2), 207-237.

Darwazeh, A. N., \& Branch, R. M. (2015). A revision to the revised bloom's taxonomy. A proceeding paper presented at the annual meeting of the American association for educational communications and technology. Edit. Michael Simonson IN: Indianapolis (Nov., 3-7 2015).

Dindar, H., \& Demir, M. (2006). Beşinci sınıf öğretmenlerinin fen bilgisi dersi sınav sorularının Bloom taksonomisine göre değerlendirilmesi. Gazi Üniversitesi Eğitim Fakültesi Dergisi, 26(3), 87-96.

Durukan, E., \& Demir, E. (2017). 6, 7 ve 8. Sınıf Türkçe dersi öğrenci çalışma kitaplarındaki etkinliklerin Bloom'un yenilenmiş taksonomisine göre sınıflandırılması. Uluslararası Türkçe Edebiyat Kültür Eğitim Dergisi, 6(3), 1619-1629.

Edwards, N. (2010). An analysis of the alignment of the grade 12 physical sciences examination and the core curriculum in South Africa. South African Journal of Education, 304(4), 571-590.

Eke, C. (2015). Dalgalar ünitesindeki kazanımların yenilenmiş Bloom taksonomisine göre incelenmesi. Ĕ̌gitim ve Öğretim Araştırmaları Dergisi, 4(2), 345-353.

Ermurat, D. G., Gümüş, İ., Kurt, M., \& Feyatörbay, E. (2011). İlköğretim fen bilgisi dersinde sorulan sinav sorularının Bloom taksonomisine göre analizi (Erzurum örneği). EKEV Akademi Dergisi 15(49), 261-269.

Eroğlu, D., \& Sarar-Kuzu, T. (2014). Türkçe ders kitaplarındaki dil bilgisi kazanımlarının ve soruların yenilenmiş Bloom taksonomisine göre değerlendirilmesi. Başkent Üniversitesi Eğitim Dergisi, 1(1), 72-80.

Geçit, Y., \& Yarar, S. (2010). 9. Sınıf coğrafya ders kitabındaki sorular ile çeşitli coğrafya sorularının Bloom taksonomisine göre analizi. Marmara Coğrafya Dergisi, 22, 154-167.

Gezer, M., Şahin, G.F., Öner-Sünkür, M., \& Meral, E. (2014). 8. Sınıf T.C İnkılap tarihi ve Atatürkçülük dersi öğretim programı kazanımlarının revize edilmiş Bloom taksonomisine göre değerlendirilmesi. Bartın Üniversitesi Ĕgitim Fakültesi Dergisi, 3(1), 433-435.

Gökler, Z. S., Aypay, A., \& Arı, A. (2012). İlköğretim İngilizce dersi hedefleri kazanımları SBS soruları ve yazılı sınav sorularının yeni Bloom taksonomisine göre değerlendirilmesi. Eğitimde Politika Analizi Dergisi, l(2), 115-133.

Gökulu, A. (2015). Sınıf öğretmeni adaylarının “Isı, sıcaklık, hal değişimi kavramlarını anlama seviyelerine ilişkin bir çalışma. Mersin Üniversitesi Ĕ̆itim Fakültesi Dergisi, 11 (2), 300-314.

Guskey, T., \& Sparks, D. (1996). Exploring the relationship between staff development and improvements in student learning. Journal of staff Development, 17(4), 34-38

Güler, G., Özdemir, E., \& Dikici, R. (2012). İlköğretim matematik öğretmenlerinin sınav sorular1 ile SBS matematik sorularının Bloom taksonomisi’ ne göre karşılaştırmalı analizi. Erzincan Üniversitesi Eğitim Fakültesi Dergisi, 12(1), 41-60.

Gündüz, Y. (2009). İlköğretim 6, 7 ve 8. sınıf fen ve teknoloji sorularının ölçme araçlarına ve Bloom’un bilişsel alan taksonomisine göre analizi. Yüzüncü Yll Üniversitesi Eğitim Fakültesi Dergisi, 4(2), 150-165.

Güven, Ç., \& Aydın, A. (2015, Eylül). 8. Sınıf fen ve teknoloji dersi ögretim programında bulunan soruların yenilenmiş Bloom taksonomisi ile göre incelenmesi. IV. Ulusal kimya eğitimi kongresi özet kitab1, Balıkesir Üniversitesi Necatibey Eğitim Fakültesi, (7-10 Eylül 2015) 101.

Karaer, H (2019). Yenilenmiş bloom taksonomisine göre soru analizi (KPSS/ÖABT-Analitik kimyayla ilişkili sorular). Kastamonu Eğitim Fakültesi Dergisi, 27(6), 2583-2596.

Karaer, H., Karaer, F., \& Kartal, E. (2018). Kamu personeli seçme sınavlarındaki öğretmenlik alan bilgisi terslerine yönelik öğretmen adaylarının görüşleri. Erciyes Ĕgitim Dergisi, 2(2), 40-58.

Karaman, İ. (2005). Erzurum ilinde bulunan liselerdeki fizik sınav sorularının Bloom taksonomisinin basamaklarına göre analizi. Gazi Üniversitesi Gazi Eğitim Fakültesi Dergisi, 25(1), 77-90.

Korkmaz, F., \& Ünsal, S. (2015). Bloom'un yenilenmiş taksonomisine göre bir sınav analizi. Turkish Journal of Education, 5(3), 170-183.

Köğce, D., \& Baki A. (2009). Farklı türdeki liselerin matematik sınavlarında sorulan soruların Bloom taksonomisine göre karşılaştırılması, Kastamonu Ĕgitim Dergisi 17(2),557-574.

Krathwohl, D. R. (2002). A revision of Bloom's taxonomy: An overview. Theory into Practice, 41(4), $212-264$.

Mohammadi, E., Kiany, G., Ghafar Samar, R., \& Akbari, R. (2015). Appraising pre-service EFL teachers' assessment in language testing course using revised Bloom's taxonomy. International journal of Applied Linguistic \& English literature, 4(4), 8-20. 
Oktay, A. (1991). Öğretmenlik mesleği ve öğretmenin nitelikleri. M.Ü. Atatürk Eğitim Fakültesi Eğitim Bilimleri Dergisi, 3, 187-193.

Omara, N., Harisa, S.S., Hassana, R., Arshada, H. Rahmata, M., Zainala, N.F.A., \& Zulkifli, R. (2012). Automated analysis of exam questions according to Bloom's taxonomy. Procedia-Social and Behavioural Sciences, 59, 297-303.

Özdemir, S. M., Altıo, S., \& Baki, N. (2015). Bloom'un yenilenmiş taksonomisine göre sosyal bilgiler öğretim programı kazanımlarının incelenmesi. Ĕgitim ve Öğretim Araştırmaları Dergisi, 4(3), 363-375.

Özer-Keskin, M., \& Aydın, S. (2011). Seviye belirleme sınavı 6. sınıf fen ve teknoloji testinde çıkan biyoloji sorularının revize edilmiş taksonomiye göre incelenmesi. Gazi Üniversitesi Gazi Eğitim Fakültesi Dergisi, 31(3), 727-742.

Sabuncuoğlu, O. (2016). Öğretmen gözlemlemenin öğrenmeyi öğrenmedeki yeri nedir: Öğretmenin kariyerinde fark yaratabilir mi? Atatürk Üniversitesi Sosyal Bilimler Enstitüsü Dergisi, 20(1), 185-198.

Seo, Y. J., Kim, H. S., \& Chae, H. K. (2010). Analysis of the end-of-chapter questions in chemistry II according to revised Bloom's taxonomy of educational objectives. Journal of the Korean Chemistry Society, 54(3), 329-337.

Sünbül, A. M. (1996). Öğretmen niteliği ve öğretimdeki rolleri. Kuram ve Uygulamada Ĕgitim Yönetimi Dergisi, 8, 597-607.

Şahin, C., \& Demir, F. (2016). Türkçe öğretmen adaylarının Türkçe öğretmenliği alan sınavına yönelik algıları. Eğitimde Kuram ve Uygulama, 12(4), 979-992.

Şanlı, C., \& Pınar, A (2017). Sosyal bilgiler dersi sınav sorularının yenilenen Bloom taksonomisine göre incelenmesi. İlkögrretim Online, 16 (3), 949-959.

Tanık, N., \& Saraçoğlu, S. (2011). Fen ve teknoloji yazılı sorularının yenilenmiş Bloom taksonomisine göre incelenmesi. Türk Bilim ve Araştırma Vakfi Bilim Dergisi, 4(49, 235-246.

Taşan, D., \& Bektaş, O. (2016). Fen bilgisi öğretmen adaylarının kamu personeli seçme sınavlarına ilişkin görüşleri. Kırşehir Eğitim Fakültesi Dergisi, 17(3), 81-100.

Tikkanen, G., \& Aksela, M. (2012). Analysis of finish chemistry matriculation examinations questions according to cogitative complexity. Nordic Studies in Science Education, 8(3), 258-268.

Topçu, E. (2017). TEOG Tarih sorularının yenilenmiş Bloom taksonomisine göre analizi. Uluslararası Türk Ĕgitim Bilimleri Dergisi, 5(9), 321-335.

Tsaparlis, G., \& Zoller, U. (2003). Evolution of higher vs. lower-order cognitive skills-type examination in chemistry: implications for university in class assessment and examinations. University Chemistry Education, 7(2)- 50-57.

Tutkun, Ö.F., \& Okay, S. (2011, Ağustos). Bloom 'un yenilenmiş taksonomisi. I. Uluslararası Eğitim Programları ve Öğretim Kongresi, Anadolu üniversitesi, Eskişehir, Türkiye.

Tutkun, Ö.F., Demirtaş, Z., \& Gür-Erdoğan, D. (2015). Revize Bloom taksonomisinin genel yapısı, gerekçeler ve değişiklikler. The Journal of Academic Social Science Studies, 32(3),57-62.

Tutkun, Ö.F., Demirtaş, Z., Gür-Erdoğan, D., \& Arslan, S. (2005). Bloom orijinal bilişsel alan sınıflaması ile yenilenmiş sınıflamanın karşılaştırılması. Akademik Sosyal Araştırmalar Dergisi, 3(10), 350-359.

Upahi, J. E., Issa, G. B., \& Oyelekan, O. S. (2015). Analysis of senior school certificate examination chemistry questions for higher-order cognitive skills. Cypriot Journal of Educational Sciences, 10(3), 218-227.

Üner, S. Akkuş, H., \& Kormalı, F. (2014). Ortaöğretim kimya ders kitaplarındaki ve sınavlarındaki soruların bilişsel düzeyi ve öğrencilerin bilişsel düzeyiyle ilişkisi. Ahi Evran Üniversitesi Eğitim Fakültesi Dergisi, 15(1), 137-154.

Yıldırım, A., \& Şimşek, H. (2013). Sosyal bilimlerde nitel araştırma yöntemleri (9. baskı). Seçkin yayıncılık, Ankara.

Yılmaz, Ö. (2016). Fen ve teknoloji öğretmen adaylarının KPSS'ye yönelik görüşlerinin incelenmesi. International Journal of Eurasia Social Sciences, 7(22), 181,194.

Yurdabakan, İ. (2012). Bloom'un revize edilen taksonomisinin eğitimde ölçme ve değerlendirmeye etkileri. Gaziantep Üniversitesi. Sosyal Bilimler Dergisi, 11(2), 327-348. 
Ek 1.

KPSS-ÖABT organik kimya sorularının analizinde kullanılan şablon

\begin{tabular}{|l|l|l|}
\hline Testin Adı: & Testin Yılı: & Testteki Soru No: \\
\hline & İsim Kısmı: \\
& Fiil Kısmı: \\
& Bilişsel Süreç Boyutu: \\
& Alt Basamağı: \\
& Bilgi Boyutu: \\
& Alt Basamağı: \\
& YBT Tablosunda Yeri: \\
& YBT Tablosunda Gösterimi: \\
\hline Açılklama: & \\
& \\
& \\
\end{tabular}

